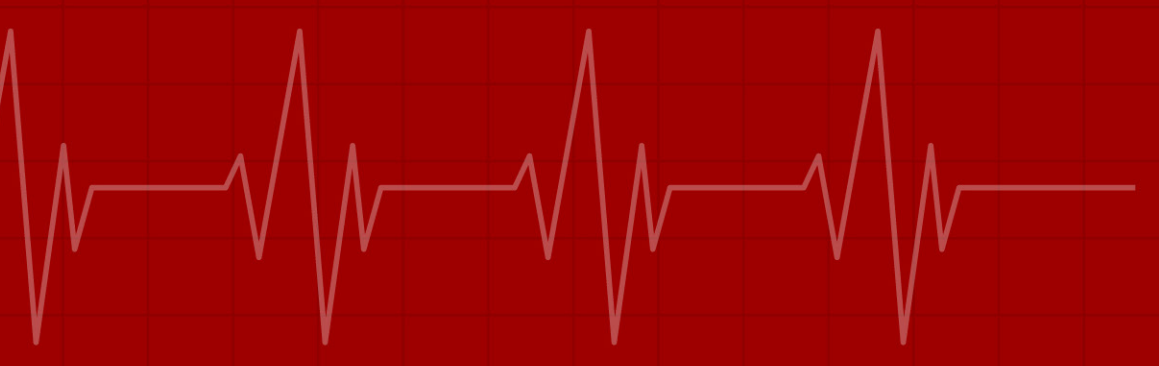

Case Report

\title{
Journal of Emergency
} Medicine Case Reports

\section{Acute Kidney Injury After Near-Drowning In A Pool Case Report}

Joo Shiang ANG

Tan Tock Seng Hospital

\begin{abstract}
Introduction: Acute kidney injury is a neglected complication of submersion injury

Case Report: A young man presented to a hospital after a near drowning event. He was clinically stable and discharged well from the hospital. He sought medical attention few days later for non-specific symptoms. His was found to have to severe acute kidney injury despite being fairly well and clinically stable. He was treated and recovered without need for hemodialysis.

Conclusion: Acute kidney injury presents in a delayed fashion after submersion injury. Acute kidney injury may not be apparent immediately after a drowning event and victims should be re-evaluated for acute kidney injury a few days after the initial event.

Keywords: Submersion, drowning, acute kidney injury, acute renal failure, rhabdomyolysis
\end{abstract}

\section{Introduction}

Drowning is a traumatic scenario that is uncommonly encountered. Pulmonary and neurologic complications are the most worrying. Healthcare providers tend to neglect other less apparent complications when the victim is well.

\section{Case Report}

A 35 year old male with no past medical history of note, first presented to the Emergency Department (ED) of another hospital after a near-drowning (ND) incident. He was swimming in a pool (freshwater) together with his young son who was seated around his shoulder. At one point his son panicked and struggled and grabbed patient around his neck, resulting in him submerging on and off underwater. The duration of struggle was less than 2 minutes and there was no loss of consciousness. He was able to pull himself out of the water after a passerby threw him a float. He felt generalized weakness, slightly breathless and nauseous after that.

His initial parameters in the ED were temperature $35.8^{\circ} \mathrm{C}$, pulse rate $108 / \mathrm{min}$, blood pressure $129 / 58 \mathrm{mmHg}$, respiratory rate $18 / \mathrm{min}$ and oxygen saturation of $99 \%$ on room air. Physical examination was largely unremarkable except cold peripheries. His chest x-ray was clear and he was discharged well on the same day with temperature at $37.2^{\circ} \mathrm{C}$ and oxygen saturation at $100 \%$ on room air.

He attended our ED 3 days later with non-specific symptoms. His chief complaint was feeling lethargic since then, associated with nausea and having a metallic taste in his mouth. Other complaints include vomiting 1-2 times a day, mild upper abdominal discomfort, feeling feverish, mildly breathless and low backache. His oral intake decreased past few days but he was still passing same amount of urine with no discoloration. His parameters then were temperature $36.9^{\circ} \mathrm{C}$, pulse rate $71 / \mathrm{min}$, blood pressure $129 / 65 \mathrm{mmHg}$, respiratory rate $19 / \mathrm{min}$ and oxygen saturation of $98 \%$ on room air. Physical examination was again unremarkable. His chest x-ray was clear. However, laboratory investigations revealed elevated creatinine $(\mathrm{Cr})(1065 \mu \mathrm{mol} / \mathrm{L})$ and urea (20.5 mmol/L). His venous blood gas showed a $\mathrm{pH}$ of 7.38 , pCO2 of $30 \mathrm{mmHg}$, bicarbonate $18 \mathrm{mmol} / \mathrm{L}$, base excess of -7 and lactate of $0.54 \mathrm{mmol} / \mathrm{L}$. His creatine kinase $(\mathrm{CK})$ was also found to be elevated at $25404 \mathrm{U} / \mathrm{L}$.

He was started on intravenous hydration and admitted. Aggressive intravenous hydration was commenced with good urine output. He was reviewed by Nephrology and started on oral sodium bicarbonate. An ultrasound of the 
kidneys and bladder showed both kidneys of normal size but increased renal echogenicity. His $\mathrm{Cr}$ levels increased to a peak of $1267 \mu \mathrm{mol} / \mathrm{L} 3$ days after admission (6 days after ND event) before improving while his CK levels steadily decreased after hydration. He was not started on dialysis. Patient reported improvement in symptoms only after 2-3 days of treatment. He was discharged well 9 days after admission with a creatinine of $152 \mu \mathrm{mol} / \mathrm{L}$, urea of $8.9 \mathrm{mmol} / \mathrm{L}$ and creatine kinase of $103 \mathrm{U} / \mathrm{L}$. His creatinine levels 7 weeks after the ND incident was back to normal levels.

\section{Discussion}

Acute kidney injury (AKI) in drowning cases had been described previously but due to its scarcity and poorly understood mechanism, it is often under-recognized.

Commonly described mechanisms for AKI in drowning include:

Renal hypoxic ischemia (from hypoxemia from pulmonary insufficiency or systemic hypotension) with subsequent reperfusion injury

$\square$ Rhabdomyolysis
Other mechanisms:

- Hypothermia (may or may not be associated with drowning) induced renal impairment has been described. Reduced renal blood flow is considered as the mechanism although the specific pathophysiology is unknown

$\square$ Profound renal vasoconstriction due to intense sympathetic activity and stress-related release of angiotensin II with resulting renal hypoperfusion and hypoxia ${ }^{1}$

$\square$ Increased oxygen demand for tubular transport (due to enhance solute delivery and reactive oxygen species mediated mechanisms at the cellular level) ${ }^{11}$

$\square$ Unknown

This is an unusual case of acute kidney injury (AKI) associated with drowning. Most cases of acute kidney injury in the context of drowning are in the context of severe hypoxemia with multi-organ involvement. A retrospective analysis of 95 cases by Gorelik et al. ${ }^{1}$ this year also showed that $\mathrm{AKI}$ in drowning is associated with need for resuscitation, mechanical ventilation and with the degree of acidemia, lactemia, and ventilatory failure. In this case, the patient was relatively well with stable vital signs, not requiring any form of supplemental oxygen or hemodynamic support.

Table 1. Summary of cases of delayed diagnosis of AKI in well victims

\begin{tabular}{|c|c|c|c|c|c|c|c|c|c|}
\hline $\begin{array}{c}\text { Case } \\
\text { Report }\end{array}$ & $\begin{array}{c}\text { Type of } \\
\text { presentation }\end{array}$ & $\begin{array}{c}\text { Year of } \\
\text { publication }\end{array}$ & $\begin{array}{c}\text { Type of } \\
\text { water body }\end{array}$ & $\begin{array}{l}\text { Time from } \\
\text { drowning } \\
\text { to presenta- } \\
\text { tion (days) }\end{array}$ & $\begin{array}{l}\text { Duration } \\
\text { of observa- } \\
\text { tion during } \\
\text { first visit } \\
\text { (hours) }\end{array}$ & $\begin{array}{l}\text { Time } \\
\text { between } \\
\text { initial and } \\
2^{\text {nd }} \text { visit } \\
\text { (days) }\end{array}$ & $\begin{array}{l}\text { Presenting } \\
\text { complaint }\end{array}$ & $\begin{array}{l}\text { Peak creatinine } \\
\text { levels }(\mu \mathrm{mol} / \mathrm{L})\end{array}$ & $\begin{array}{l}\text { Hemodialy- } \\
\text { sis required }\end{array}$ \\
\hline $\mathrm{Amir}^{3}$ & Delayed & 2013 & Fresh & 4 & - & - & $\begin{array}{l}\text { Flank pain, } \\
\text { nausea, loss } \\
\text { of appetite, } \\
\text { polyuria }\end{array}$ & $\begin{array}{l}1213 \text { (5 days after } \\
\text { incident) }\end{array}$ & Unknown \\
\hline $\operatorname{Logan}^{4}$ & Delayed & 2017 & Sea & 1 & - & - & $\begin{array}{l}\text { Nausea, } \\
\text { fatigue }\end{array}$ & $\begin{array}{l}451 \text { ( } 3 \text { days after } \\
\text { incident) }\end{array}$ & No \\
\hline Hegde $^{5}$ & Delayed & 2003 & Sea & 2 & - & - & $\begin{array}{l}\text { Myalgia, red- } \\
\text { dish urine and } \\
\text { subsequent } \\
\text { anuria }\end{array}$ & $\begin{array}{c}707 \text { ( } 2 \text { days after } \\
\text { incident) }\end{array}$ & Yes \\
\hline $\mathrm{Alp}^{6}$ & Reattendance & 2016 & Sea & Immediate & 24 & 2 & $\begin{array}{l}\text { Nausea, flank } \\
\text { pain, vom- } \\
\text { iting }\end{array}$ & $\begin{array}{c}707 \text { (3 days after } \\
\text { incident) }\end{array}$ & No \\
\hline Seong $^{7}$ & $\begin{array}{c}\text { Delayed } \\
\text { Reattendance }\end{array}$ & 2012 & Lake & 3 & 12 & 3 & $\begin{array}{l}\text { Tiredness, } \\
\text { anorexia, } \\
\text { anuria }\end{array}$ & $\begin{array}{l}1017 \text { ( } 6 \text { days after } \\
\text { incident) }\end{array}$ & Yes \\
\hline Hottelart $^{8}$ & Reattendance & 2004 & Lake & Immediate & 24 & 5 & $\begin{array}{l}\text { Tiredness, } \\
\text { anuria }\end{array}$ & $\begin{array}{l}1600 \text { (6 days after } \\
\text { incident) }\end{array}$ & Yes \\
\hline $\begin{array}{l}\text { Current } \\
\text { case }\end{array}$ & Reattendance & Pending & Fresh & Immediate & $<6$ & 3 & $\begin{array}{l}\text { Lethargic, } \\
\text { nausea, me- } \\
\text { tallic taste in } \\
\text { mouth }\end{array}$ & $\begin{array}{c}1267 \text { (6 days after } \\
\text { incident) }\end{array}$ & No \\
\hline
\end{tabular}


A case series of 30 patients by Spicer et al. ${ }^{2}$ in 1999 showed serum bicarbonate, $\mathrm{pH}$ and base excess to be predictors of AKI in drowning on univariate logistic regression analysis. Base excess was the best predictor by multivariate logistic regression analysis.

Our literature search revealed that AKI in seemingly well victims of near drowning is often diagnosed after a delay of a few days from the initial event. This is due to victims presenting late ${ }^{3-5}$ or due to AKI not being evident or picked up during the immediate medical visit post drowning ${ }^{6-8}$ and only detected the $2^{\text {nd }}$ time the victims re-attended. Summary of the cases is shown in Table 1. Similarly, AKI in our case is only picked up 3 days after the initial near-drowning event even though the patient had been evaluated at a medical facility immediately after the event.

AKI often continues to progress beyond the initial presentation as seen in case reports. ${ }^{4,9,10}$ Serum creatinine of $67 \%$ of patients with AKI continued to peak beyond the first day in the case series by Spicer. ${ }^{2}$ The case series by Gorelik ${ }^{1}$ noted that mean creatinine levels reached a maximum at 48 hours from presentation for cases with higher degree of renal impairment.

\section{Conclusion}

We suggest that for all near-drowning or immersion cases, a 24 hour period of observation in the emergency department observation unit may not be enough to pick up AKI and that provision should be made for a follow-up re-evaluation after a few days if the victim is deemed well enough to be discharged from the ED following an immediate presentation after near-drowning.

\section{References}

1. GorelikY, Darawshi S, Yaseen H. et al. Acute Renal Failure Following Near-Drowning. Kidney Int Rep. 2018 Mar 1;3(4):833-840.

2. Spicer ST, Quinn D, Nyi Nyi NN. et al. Acute renal impairment after immersion and near-drowning. J Am Soc Nephrol. 1999 Feb;10(2):382-6.

3. Amir A, Lee YL. A case of acute kidney injury by near-drowning. Malays Fam Physician. 2013 Dec 31;8(3):34-6.

4. Ian R. Logan, Alison L.Brown. Severe acute kidney injury associated with immersion into seawater. Cogent Medicine (2017), 4: 1297190.

5. Hegde SN, Anupama YJ. Acute renal failure secondary to rhabdomyolysis following near-drowning in sea water. J Assoc Physicians India. 2003 May;51:512-3.

6. Alp A, Akdam H, Meteoğlu İ. et al. Acute kidney injury after near drowning: The way from the beach to hemodialysis. Hemodial Int. 2016 Jan;20(1):E1-4.

7. Seong EY, Rhee $H$, Lee N. et al. A case of severe acute kidney injury by near-drowning. J Korean Med Sci. 2012 Feb;27(2):218-20.

8. Hottelart C, Diaconita M, Champtiaux B. et al. When the kidney catches a cold: an unusual cause of acute renal failure. Nephrol Dial Transplant. 2004 Sep;19(9):2421-2.

9. Miki $A$, Takeda $S$, Yamamoto $H$. et al. A case of renal impairment after near-drowning: the universal nature of acute kidney injury. Clin Exp Nephrol. 2013 Aug;17(4):594-5.

10. Ma TK, Chow KM, Leung CB. et al. Near-drowning related acute kidney injury. Clin Nephrol. 2016 May;85(5):305-8.

11. Heyman SN, Gorelik Y, Zorbavel D. et al. Near-drowning: new perspectives for human hypoxic acute kidney injury. Nephrol Dial Transplant. 2019 Feb 14. 
